\title{
ICELAND AND LATVIA: THE ECONOMIC AND THE SOCIAL CRISIS
}

\author{
HiLmar PÓr HiLmarSSON ${ }^{1}$
}

University of Akureyri (Iceland)

\begin{abstract}
The 2008 global economic and financial crisis hit hard in Iceland and Latvia. Economic developments prior to the crisis, as well as response to the crisis were, however, different in these two countries, yielding different results. Both countries received assistance from the International Monetary Fund (IMF) during the crisis and the IMF has labeled their reform programs as success stories. This article reviews and evaluates the post crisis situation in Iceland and Latvia, both in terms economic performance, as well as social progress. It also discusses how other countries, as well a multilateral institutions, may have influenced the reform programs in Iceland and Latvia.
\end{abstract}

KEY WORDS: Small states, Latvia and Iceland, global crisis, economic policy, privatization.

JEL CODES: H12, E63, L33

DOI: http://dx.doi.org/10.15181/rfds.v14i3.866

\section{Introduction}

The 2008 global economic and financial crisis hit hard in Iceland and Latvia. Both countries responded, but in a different way. In terms of fiscal adjustment the governments of both countries implemented painful budget cuts although the front loaded fiscal austerity program in Latvia was more radical. When it comes to exchange rate policy the response was different. Latvia, an EU member state, maintained fixed exchange rate, the Lat pegged to the Euro. In contrast the Icelandic krona depreciated sharply and the government introduced a policy of capital controls ${ }^{2}$. Latvia received extensive external assistance during the crisis while Iceland was isolated and "friendly" nations hesitated to get involved and some were hostile?.

When crisis of this magnitude hit small countries like Iceland and Latvia are challenged to respond to the immediate economic and social problems that follow and decide whom to work with to resolve them,

1 Hilmar Pór Hilmarsson - PhD Professor, University of Akureyri, Iceland, Visiting Scholar University of Washington, USA. Scientific interests: Economic Policy

E-mail: hilmar@unak.is.

Tel.: +3548498380

2 While Iceland is not a member of the European Union it is part of the Euorpean Economic Area where labor, goods, services and capital are to flow freely. Captial controls are inconsistent with this policy, but in the case of Iceland the international community thorugh the IMF, and thus the EU, accepted capital controls in Iceand. The questions remains how long this policy will be accepted and when the government of Iceland is prepared to remove these controls.

3 Faroe Islands, Poland and Russia were the only countries that supported Iceland from the beginning. Scandinavian countries initally hesitated to get involved. The UK was very hostile. Iceland's dispute with the UK and the Netherlands, because of the so called ICESAVE accounts,may have influnenced the Scandinavian Countries. The government of Iceland probably overestimated potential support from the Scandinavian countries who were more likely to serve their own economic and political interests in the UK and in the Netherlands, than supporting Iceland during a period of crisis and uncertanty. 
including the IMF, the EU and other countries. The objective of this article is to compare how these two small countries responded in terms of economic policy, which institutions and countries they cooperated with, and with what results in terms of economic growth and social progress.

After more than 5 years since the crisis erupted sufficient time has passed for observers to begin seeing the outcomes from the different policy responses, both in terms of economic performance and social progress, and it is maybe time to see what lessons can be learned, for Latvia and Iceland and perhaps also for the European Union and the Euro area. In addition to reviewing the economic performance of those two countries in terms of GDP growth and unemployment, among the tasks of this article is also to consider their post crisis performance based on newly developed indicators that also measure poverty and social exclusion. The purpose is to highlight that it is insufficient to only look at countries economic growth performance to measure the success of their reform programs. Social outcomes are also important and affect long term economic growth.

The methodology used in this article is the case study method. Compared to other research methods, a case study enables the researcher to examine the issues at hand in greater depth. According to Yin (Yin, 2009: 101-102) six sources of evidence are most commonly used in case studies. These are: documentation, archival records, interviews, direct observations, participant-observation, and physical artifacts. Each of these sources has advantages and disadvantages and according to Yin one should "note that no single source has a complete advantage over all the others. In fact, the various sources are highly complementary, and a good case study will therefore want to use as many sources as possible" (Yin, 2009: 101).

Among the sources of evidence used for the analysis in this article are documentation/secondary data, including reports and scholarly literature, articles and books. Direct observation also plays a role in this article as the author draws on his experience and observations while living in Iceland prior to and during the crisis and having worked for the World Bank in Latvia for four years. However, preference was given to using welldocumented evidence that is publicly available and listed in the references. This case study does not present results that can be evaluated on the basis of statistical significance and one should be careful in generalizing the findings of one case study onto another case or situation. However, some lessons from the study could have wider relevance than for Iceland and Latvia only. This is especially true for small countries with a large banking sector, using their own currency, and with limited fiscal space to support the banks during a crisis.

\section{Iceland and Latvia and the success of their reform programs}

In 2011 the sitting prime minister of Latvia co-authored a book, "How Latvia Came through the Financial Crisis". This book presents Latvia's reform program as a success story, and an example of how crisis should be resolved (Åslund, Dombrovskis, 2011). The authors even suggested Latvia as a success story for the rest of the world to follow. This article will look at this "success story" both from the viewpoint to economic developments as well as social progress.

Iceland has not been presented as a success story this way, but it followed an unconventional path with a large depreciation and the introduction of capital controls. Practically the whole banking system collapsed in few days in Iceland while the banking system in Latvia, with the exception of Parax bank, was rescued.

While Iceland and Latvia are both small European countries hit hard by the crisis it is important to keep in mind that in many ways they are very different. They have their own history and culture and they are at a different stage of development, economically and socially. Iceland remains outside the EU while Latvia has been an EU member for ten years. According to World Bank classifications Iceland is a high income OECD country while Latvia remains on the margin of an upper middle income and high income country and is still in transition where poverty and social exclusion remains a concern.

The fact that Iceland and Latvia are small countries that were severely affected by the crisis and responded differently makes them an interesting comparator case. Nevertheless, because the countries are different this article will also make reference to other high and middle income countries in Europe when thought to be relevant and useful. 


\section{Economic growth and social progress in the European Union (EU)}

While the focus here is on Iceland and Latvia, the study can also have relevance for other countries. Important lessons maybe learned about the effects of different policy responses during times of crisis, including in the European Union and the Euro area. In fact, among the main reasons for new member states to seek membership in the EU has been its economic success. For the time being this success has disappeared. Both the EU and the Euro area continue to experience slow economic growth and high unemployment especially among its youth. Poverty and social exclusion is an increasing concern within the EU and income inequality is alarming in some countries. High levels of long term unemployment within the EU will without doubt influence long term growth in the area, but little attention has been given to this matter so far.

Iceland recently decided not to continue with its accession negotiation with the EU and the negotiation team has been dissolved. Benefits of EU membership are in doubt, at least for the time being, and too many people feel that the EU has not adequately dealt with its problems, including a sick banking system where the strategy seems to be to buy time. There also seems to be a tendency to impose additional burden on taxpayers to keep the financial sector going and social problems are alarming, including dismal prospects for young people to find jobs.

\section{Was there "government ownership" of economic policies?}

When the crisis hit Iceland and Latvia the response in the two countries was very different. In reality Iceland had no choice other than let its national currency depreciate sharply. The depreciation in nominal terms was about 50 percent. Limited fiscal space and insufficient reserves in the Central Bank of Iceland meant that Iceland did not have capacity to defend its currency. This is clear and obvious and all statements that Icelandic government decided to depreciate its currency do not hold water. Iceland was isolated, and sufficient international assistance to defend its local currency, could not be assembled.

Latvia on the other hand went for internal devaluation attempting to cut wages (mainly public) and prices sharply. This response was consistent with its goal to adopt the Euro which it in January 2014. Latvia's policy response was supported by a large international rescue package worth 7.5 billion Euros, then about one third of Latvia's GDP. This package was provided by the International Monetary Fund (IMF), the European Union (EU), the European Bank for Reconstruction and Development (EBRD), the World Bank, and bilaterally by countries, especially Scandinavian that had made large investments in the banking sector. Even one of the Baltic State's, Estonia, offered assistance to Latvia. Latvia's adoption of the Euro required a peg with the Euro and this international effort enabled to Latvia fulfil its commitments.

Iceland, a non EU member, could not relay on the EU as Latvia did. Iceland could also not go to the World Bank or the EBRD since Iceland is a high income OECD donor country. Latvia with its EU membership and middle income status, when the crisis hit, had access to the multilateral development banks. In addition to this the foreign owners of the banks in Latvia were not passive bystanders during the crisis. They defended their own interests.

The Latvian government claims to have decided to keep a fixed exchange rate regime in Latvia, while the IMF initially suggested 15 percent depreciation. The policy to keep the exchange rate fixed was, however clearly favored by external interests, especially Scandinavian banks who owned most of the Latvian banking system and the European Union. EU interests feared the effects of a large depreciation on the banking sector in the other Baltic States and the Scandinavian countries that then could spill over to other EU member countries. Disorderly devaluation would have caused a Swedish Banking crisis (Åslund, Dombrovskis, 2011: 116).

When the banks were privatized in Iceland, they were sold to local interests or more precisely local actors with political interests and connections (see. e.g. Hilmarsson, 2013). No foreign investment was made in the Icelandic banks and no foreign banks were operating in Iceland when the crisis hit. This was fundamentally different in Latvia where foreign investors became the owners of the banking system, except for Parex 
bank. Given the size of the banking system in Iceland, with total assets more than nine times GDP ${ }^{4}$ the local government had no choice other than let the banks fall. In Latvia the mostly foreign owned banking system was rescued via a concerted international effort lead by external interests. It is highly questionable if Latvian government had any choice other than to rescue the banks if it wanted to keep good standing within the EU.

The IMF likes to talk about a strong government ownership of the reform program in Iceland and Latvia. In the initial phases of the crisis there was hardly much ownership in Iceland as there was only one way to go, sharp exchange rate depreciation and the collapse of the major banks. Latvian government ownership is also in doubt. As the IMF sais "The European Commission was heavily involved in program design, especially in the fiscal and financial sectors" (IMF, 2012: 7). Åslund and Dombrovskis state in their book when discussing the government's aggressive cuts in the education and health sectors: "Reform starts where the money ends" (Åslundand, Dombrovskis, 2011: 73). The policy was chosen because the flow of outside money had ended, not because the government or the people wanted to go this path. The foreign owned banks also had a strong voice and as IMF's chief economist said in a recent article "if your financial sector is largely composed of foreign subsidiaries, it is a good idea to be friends with the parent banks" (Blanchard, et al, 2013: 33).

During the crisis capital controls were introduced in Iceland, but not in Latvia. The decision to introduce capital controls was supported by the IMF, and thus also the EU, whose member states are represented at IMFs board of directors. Those controls were introduced as a temporary measure. Capital controls helped prevent the currency from depreciating further than it did. Nevertheless the sharp depreciation resulted in balance sheet problems for household and corporate that still remain a hotly debated issue in Iceland. Adjustment in corporate and household debts is debated and the current government has introduced a large package of debt relief for households that it may have problem delivering on when considering the limited fiscal space available to policy makers. The government plans to implement extensive tax cuts and large write-downs of household debt in the next 4 years. There is a high risk of free riding here. Those who took high risks and borrowed excessively will be allowed to impose costs on those who where more modest in their investments and borrowed little or nothing. Those who purchased more modest homes or rented a place to live will be punished. This is a dangerous path chosen by the government of Iceland.

In conclusion, it can be argued that neither Iceland nor Latvia had a choice when the crisis hit. Iceland could not save its banks and had little international support. Only after its banking system had collapsed did outside support emerge. In the case of Latvia, it also had no choice. External interests took control with a large rescue package. No country wanted to save the locally owned Icelandic banks, but in Latvia the foreign owners were keen to protect the financial system that was mostly in their ownership. The EU also feared domino effects of a banking collapse in Latvia and acted swiftly, overruling the IMF's initial advise for a 15 percent depreciation of the Lat.

\section{Economic outcomes in Iceland and Latvia}

During the crisis Latvia suffered the greatest fall in GDP of any country in the world, around 23 percent. Iceland was less affected with GDP falling about 10 percent, see table 1. Prior to the crisis Latvia and Iceland had unusually large current account deficits - over 20 percent of GDP (see table 1; Latvia's current account deficit in 2007 was 22.4 percent of GDP).

Imports declined by about 40 percent in Iceland and Latvia during the crisis and investment collapsed in both countries. Private consumption declined during the crises but growth has resumed in both countries. Both countries cut their government budget but public consumption adjusted more in Latvia than in Iceland (Darvas, 2011).

4 According to the IMF the consolidated assets of the three main Icelandic banks increased from 100 percent of GDP in 2004 to 923 percent at end 2007, reflecting expansion overseas. By end 2007, almost 50 percent of the three banks' assets were held abroad (IMF, 2008: 11). 
Table 1. Real GDP, Consumer Prices, Current Account Balance, and Unemployment

\begin{tabular}{|c|c|c|c|c|c|c|c|}
\hline Iceland & 2008 & 2009 & 2010 & 2011 & 2012 & 2013 & 2014 \\
\hline & & & & & & \multicolumn{2}{|c|}{ Projections } \\
\hline Real GDP & 1.2 & -6.6 & -4.1 & 2.9 & 1.6 & 1.9 & 2.1 \\
\hline Consumer prices* & 12.7 & 12.0 & 5.4 & 4.0 & 5.2 & 3.7 & 3.1 \\
\hline Current account balance** & -28.4 & -11.6 & -8.4 & -5.6 & -4.9 & -1.2 & -1.9 \\
\hline Unemployment*** & 1.6 & 8.0 & 8.1 & 7.4 & 5.8 & 5.1 & 4.6 \\
\hline \multirow[t]{2}{*}{ Latvia } & 2008 & 2009 & 2010 & 2011 & 2012 & 2013 & 2014 \\
\hline & & & & & & \multicolumn{2}{|c|}{ Projections } \\
\hline Real GDP & -3.3 & -17.7 & -0.9 & 5.5 & 5.6 & 4.0 & 4.2 \\
\hline Consumer prices* & 15.3 & 3.3 & -1.2 & 4.2 & 2.3 & 0.7 & 2.1 \\
\hline Current account balance** & -13.2 & 8.7 & 2.9 & -2.1 & -1.7 & -1.1 & -1.3 \\
\hline Unemployment*** & 7.5 & 16.9 & 18.6 & 16.2 & 15.0 & 11.9 & 10.7 \\
\hline \multicolumn{8}{|c|}{$\begin{array}{l}\text { *) Movements in consumer prices are shown as annual averages. } \\
\text { **) Percent of GDP. } \\
* * * \text { ) National definitions on unemployment may differ }\end{array}$} \\
\hline
\end{tabular}

Source: IMF, 2013a

Overall, the economic adjustment involved larger decrease in output, larger increase in unemployment, and more emigration in Latvia than in Iceland, see table 1 and 4 . The question is whether an alternative strategy for Latvia could have achieved a better outcome, e.g. by depreciating around 15 percent as the IMF suggested. As Blanchard, et.al has stated nobody can give a definitive answer (Blanchard, et. al, 2013: 3).

After more than 5 years of adjustment, unemployment in Latvia is about 12 percent and GDP is still about 8 percent below the pre-crisis peak. Registered unemployment in Iceland is now below 4 percent. Both economies enjoy GDP growth rate that is much higher than the average EU or Euro GDP rate growth rates. Latvia's GDP growth is projected by the IMF to be around 4 percent in 2013 while Iceland's growth is projected around 2 percent ${ }^{5}$. According to Statistics Iceland, GDP increased by 3.1 percent in the first nine months of 2013 (Statistics Iceland, 2013b). Both countries have dramatically improved their current account balance and the IMF projects only a minor current account deficit in Iceland and Latvia ${ }^{6}$ in 2013 and 2014, see table 1 .

\section{Social impact in Iceland and Latvia}

If one looks at unemployment, job losses were much more dramatic in Latvia than in Iceland. As stated above unemployment in Iceland is about 4 percent but about 12 percent in Latvia, close to the EU average, and twice the pre crisis unemployment rate. As the IMF has noted in a recent report, the labor market is improving, but unemployment, especially long-term unemployment is still high in Latvia (IMF, 2013b: 4)7.

Many economists were critical of Latvia's reform program during the crisis. Nobel Prize-winning economist Paul Krugman, for example, stated that "They have made a desert, and called it adjustment" (Krugman, 2011). The sitting Prime Minister of Latvia on the other hand stated that the "The greatest pleasure in life is doing what people say you cannot do..." (Åslund, Dombrovskis, 2011: 53). The question remains what costs

The Statistical Office in Iceland reports higher GDP growth rate for Iceland than the IMF does.

For a comprehensive analysis of Latvia's recent export performance, see Vanags (2013).

It remains unclear how far unemployment needs to adjust to reach the natural rate of unemployment in Latvia. According to Blanchard et.al 2013 output has not yet reached its potential and unemployment is not back to the natural rate? But they may not be very far (Blanchard, et.al, 2013: 3). The question remains, how can a country with a low minimum wage, weak unions, limited unemployment insurance and employment protection, have such a high natural rate of unemployment.

8 Here Åslund and Dombrovskis are citing Walter Bagehot, an English economist and journalist. 
the government is prepared to impose on its people to adjust and how is this likely to affect the social fabric and long term growth in the country?

Latvia's claim to victory, post crisis, is to a large extent based on recent GDP ${ }^{9}$ growth and reduction in unemployment. It is true that according to this measure, Latvia is on a path to recovery, and its GDP growth appear to be healthy as compared with other EU11 countries and strong compared to EU15 countries currently with little or no growth. Recent data from the World Bank on Latvia, for example, show GDP growth rate of 5.6 percent in 2012, an estimate of 3.6 percent in 2013 and projection of 4.1 percent growth rate in 2014 (World Bank, 2013). The two other Baltic States, Estonia and Lithuania, also compare well with other EU11 countries. However, one needs to review these numbers in the context of post crisis growth rates where Latvia was that hardest hit country in the world and lost about 23 percent of its GDP, see table 1. After 5 years of adjustment Latvia's GDP remains 11 percent below the pre-crisis peak. Nevertheless the returning to a path of grow this a welcome development.

Economic growth in Iceland remains lower which to a large extent is due to the fact that Iceland is a very open economy with most of its exports going to the EU that has recently had little or no GDP growth at all. The second estimate for the third quarter of 2013 from Eurostat shows Euro area GDP growing by 0.1 percent and EU28 growing by 0.2 percent (Eurostat, 2013). Thus recovery in the EU remains both weak and fragile.

Few would doubt the importance of economic growth, as measured by GDP, as an indicator for the performance of an economy, but the question remains if this indicator is sufficient to support Latvia's claim to victory and to declare it a success story for other countries to follow.

\section{Measures of economic performance and social progress and their limitations}

How good is GDP as an indicator of economic and social progress in a country? It maybe worth review instatements that some Nobel prize-winning economists and policy makers have made about the importance, as well as the limitations, of GDP as an indicator economic development.

Paul Samuelsson, for example, stated that "Without measures of economic aggregates like GDP, policymakers would be adrift in a sea of unorganized data. The GDP and related data are like beacons that help policymakers steer the economy toward the key economic objectives" (Samuelson and Nordhaus, 1995). It is understandable that economists want to have a common measure of economic progress and development, but the views are diverse. The creator of GDP, Nobel Prize winning economist Simon Kuznets, once stated that "The welfare of a nation can scarcely be inferred from a measurement of national income" (European Commission, 2013). Thus the creator and promoter of this indicator recognized its obvious limitations. More recently another Nobel Laurate, Joseph Stiglitz, has stated that "No one would look just at a firm's revenues to assess how well it was doing. Far more relevant is the balance sheet, which shows assets and liability. That is also true for a country" (Foreign Affairs, 2005).

So it is clear that there are leading economists who view GDP critically including its creator who states that is does not measure the welfare of nations adequately. Regarding Stiglitz comments there are additional problems. Human capital is normally not included in company's balance sheet, yet it is critical, both to a company's profitability, and a countries growth.

Policy makers have also commented on GDP as a measure of economic development. Robert McNamara, then the president of the World Bank, for example, commented that the "Progress measured by a single measuring rod, the GNP, has contributed significantly to exacerbate the inequalities of income distribution"

9 Gross domestic product, abbreviated as GDP, is the most widely used measure of a country's overall economic health and development. As an aggregate measure of production, GDP is equal to the sum of the gross value added of all resident institutional units (i.e. industries) engaged in production, plus any taxes, and minus any subsidies, on products not included in the value of their outputs. Gross value added is the difference between output and intermediate consumption. - See, further, for example, Eurostat: http://epp.eurostat.ec.europa.eu/statistics_explained/ index.php/Glossary:Gross_domestic_product_(GDP) 
(European Commission, 2013). French president Nicolas Sarkozy once stated that "Nothing is more destructive than the gap between people's perceptions of their own day-to-day economic well-being and what politicians and statisticians are telling them about the economy" (Sarkozy, 2009). This is an interesting statement coming from someone who has played an important role in policy and decision making in the European Union.

\section{Going "beyond" Gross Domestic Product (GDP)}

Recently there has been a movement to go "beyond" GDP when measuring progress within the EU. Given the very uneven developments in the EU in terms of economic and social progress it is understandable that the EU wants a more comprehensive picture on the status within the union. The EU has also performed poorly according to the GDP measure during the crisis, especially the EU15. What story would other indicators tell about EU's economic and social progress?

The Commission on the Measurement of Economic Performance and Social Progress issued a report in $2009^{10}$. One can argue that the global economic and financial crisis has reinforced the need for additional indicators to assess the economic and social situation in the world, in particular poverty and social exclusion, risks and sustainability. GDP per capita and its growth over time does also not tell how economic benefits are shared within a society. "A 2008 Eurobarometer poll showed that more than two thirds of EU citizens feel that social, environmental and economic indicators should be used equally to evaluate progress. Only just under one sixth prefer evaluation based mostly on economic indicators" (Commission on the Euorpean Communities, 2009).

While the work based on the Report by the Commission on the Measurement of Economic Performance and Social Progress continues, and new indicators are developed and introduced, one can review some of the indicators that are currently published by Eurostat. Among those indicators are the Portion of people at-riskof-poverty or social exclusion and at-risk-of-poverty rate. Regarding income distribution Eurostat calculates the Gini index and the Income quintile share ratio; see the table 2 below for results on Iceland and Latvia.

Table 2. Risk of Poverty, Social Exclusion and Income Distribution

\begin{tabular}{|c|c|c|c|c|c|c|}
\hline Iceland & 2007 & 2008 & 2009 & 2010 & 2011 & 2012 \\
\hline $\begin{array}{l}\text { Portion of people at-risk-of poverty } \\
\text { or social exclusion }\end{array}$ & 13.0 & 11.8 & 11.6 & 13.7 & 13.7 & 12.7 \\
\hline At-risk-of-poverty rate & 10.1 & 10.1 & 10.2 & 9.8 & 9.2 & 7.9 \\
\hline The Gini index & 28.0 & 27.3 & 29.6 & 25.7 & 23.6 & 24.0 \\
\hline Income quintile share ratio & 3.9 & 3.8 & 4.2 & 3.6 & 3.3 & 3.4 \\
\hline Latvia & 2007 & 2008 & 2009 & 2010 & 2011 & 2012 \\
\hline $\begin{array}{l}\text { Portion of people at-risk-of poverty } \\
\text { or social exclusion }\end{array}$ & 36.0 & 33.8 & 37.4 & 38.1 & 40.4 & 36.6 \\
\hline At-risk-of-poverty rate & 21.2 & 25.6 & 25.7 & 21.3 & 19.1 & 19.4 \\
\hline The Gini index & 35.4 & 37.7 & 37.4 & 36.1 & 35.4 & 35.9 \\
\hline Income quintile share ratio & 6.3 & 7.3 & 7.3 & 6.9 & 6.6 & 6.5 \\
\hline
\end{tabular}

Source: Statistics Iceland, 2013a

10 The commission included Professor Joseph E. Stiglitz, Chair, Columbia University, Professor Amartya Sen, Chair Adviser, Harvard University, and Professor Jean-Paul Fitoussi, Coordinator of the Commission, IEP. 
8. Poverty, social exclusion and income equality in Latvia and in Iceland

Iceland and Latvia have both returned to healthy GDP growth rates post crisis, but how are these countries performing according to other indicators currently measured by Eurostat?

In 2012 the proportion of people at risk of poverty or social exclusion in Iceland was the lowest in Europe, but among the highest in Latvia (only Bulgaria and Romania had higher ratios than Latvia). The rate in Iceland was 12.7 percent, 36.6 percent in Latvia, but 25 percent in the European Union. When focusing on those at risk of poverty the proportion was also lowest in Iceland or 7.9 present compared to 19.4 present in Latvia and 17.1 percent within the European Union. The at-risk-of-poverty threshold is defined as 60 present of median income in each country. Those who fall below that income threshold are considered to be at risk of poverty. Latvia's distribution of prosperity as measured by the Gini coefficient is the most unequal in the EU.

One can argue that Iceland and Latvia should not be compared, using those indicators, because of the different income level. Latvia is on the margin of an upper middle and high income country, but Iceland a high income OECD country. However, one needs to keep in mind that the Czech Republic, a country with a similar income level as Latvia, has one of the lowest ratios in the European Union, both if one considers the ratios for the portion of people at-risk-of-poverty and social exclusion, as well as if one considers the at risk-of-poverty rate. Slovenia and Slovakia also perform much better than Latvia if one looks at those indicators. Also if one considers income distribution according to the Gini index and the Income quintile share ratio the Czech Republic, Slovenia and Slovakia have are among EU countries with the most even income distribution and have an income distribution that is more even than the average both in the EU(27) and the EURO(17) area.

In a recent IMF report one can find the following sentence: "Latvian authorities do believe that the current degree of inequality is unacceptable and the high level of poverty, tracing back to the collapse of the Soviet Union, should be reduced" (IMF, 2013: 2). Latvia's performance on the four accounts shown in table 2 , measuring poverty, social exclusion and income equality, must be considered poor. Latvia has been an independent country for more than 20 years (since 1991) and a member of the European Union for 10 years (since 2004). Its policy makers must pay more attention to the problems of poverty, social exclusion and income equality, if they want to present Latvia internationally as a success story, and a model to follow for the rest of the world.

According to the EU (in its report Europe 2020) there is a high level of tax on low income earners in Latvia, high youth unemployment and $40 \%$ of the population in Latvia is at risk of poverty or social exclusion - one of the highest rates in the EU (European Commission, 2012). A recent Latvia Competitiveness Report argues that "Latvia's high income inequality, is an indicator highlighting the presence of underlying competitiveness weaknesses that not only drive inequality but also negatively affect productivity" (Cunskaet et al., 2012: 17).

Table 3. Poverty, Social Exclusion and Income Distribution

\begin{tabular}{|l|c|c|c|c|c|}
\hline Countries & $\begin{array}{c}\text { GNI per capita } \\
\text { (US\$) }\end{array}$ & $\begin{array}{c}\text { Proportion of people at- } \\
\text { risk-of-poverty or social } \\
\text { exclusion }\end{array}$ & $\begin{array}{c}\text { At-risk-of- } \\
\text { poverty rate }\end{array}$ & The Gini index & $\begin{array}{c}\text { Income quintile } \\
\text { share ratio }\end{array}$ \\
\hline Iceland & 38.710 & 12.7 & 7.9 & 24.0 & 3.4 \\
\hline Latvia & 14.180 & 36.6 & 19.4 & 35.9 & 6.5 \\
\hline Bulgaria & 6.870 & 49.3 & 21.2 & 33.6 & 6.1 \\
\hline Romania & 8.420 & 41.7 & 22.6 & 33.2 & 6.3 \\
\hline $\begin{array}{l}\text { Czech } \\
\text { Republic }\end{array}$ & 18.130 & 15.4 & 9.6 & 24.9 & 3.5 \\
\hline $\begin{array}{l}\text { Slovak } \\
\text { Republic }\end{array}$ & 17.170 & 20.5 & 13.2 & 25.3 & 3.7 \\
\hline Slovenia & 22.720 & 19.6 & 13.5 & 23.7 & 3.4 \\
\hline
\end{tabular}

Source: Statistics Iceland, 2013a 
If one reviews the indicators considered by the European Union that measure social progress, Latvia seems to have much more in common with Bulgaria and Romania, than the Czech Republic and the Slovak Republic, especially when one considers income distribution. This is not a favorable outcome for Latvia given that those countries only have about half of Latvia's per capita income and are the poorest countries in the EU. Latvia needs to reform its public policy before presenting itself internationally as a success story.

\section{Emigration from Iceland and Latvia during the crisis}

Latvia has claimed victory not only on the basis of GDP growth, but also referring to reduction in unemployment. Lower unemployment certainly is a welcome development in Latvia, but one needs to keep in mind that emigration explains a part of the reduction in unemployment in both Iceland and Latvia.

According to Darvas (2013) 8.5 percent of Latvians left the country from January 12008 to January 1 2012 , but 2.3 percent in the case of Iceland, see table 4 . According to a recent survey only $20 \%$ of the emigrants who left Latvia during the crisis report an intention of coming back within 5 years (Blanchard, et. al., 2013: 30). Those who left tend to be younger Latvians with university education.

Iceland has over the decades lost people, but experience shows that a large share of those return when the economy recovers. In Latvia the largely permanent departure of the younger and more educated workers may indeed be costly for those who stay and those who leave may have little incentives to return as Latvia's per capita income remains far below EU average. In contrast Iceland's per capita income is high in the EU context so the incentives to return during normal times are more obvious than in the case Latvia.

Table 4. Population change from 1 January 2008 to 1 January 2012

\begin{tabular}{|l|l|c|c|c|c|c|}
\hline & \multicolumn{3}{|c|}{ Total population } & \multicolumn{3}{c|}{ \% change during 2008-2011 due to } \\
\hline Countries & $\begin{array}{c}\mathbf{1 / 1 2 0 0 8} \\
\text { (millions) }\end{array}$ & $\begin{array}{c}\mathbf{1} / \mathbf{1 ~ 2 0 1 2} \\
\text { (millions) }\end{array}$ & \% change & Birth & Death & $\begin{array}{c}\text { Other } \\
\text { migration) }\end{array}$ \\
\hline Latvia & 2.27 & 2.04 & -10.1 & 3.7 & -5.3 & -8.5 \\
\hline Iceland & 0.32 & 0.32 & 1.3 & 6.1 & -2.5 & -2.3 \\
\hline
\end{tabular}

Source: Darvas, 2013

\section{Conclusions}

The 2008 global economic and financial crisis hit hard in Iceland and Latvia. Economic developments prior to the crisis, as well as response to the crisis were, however, different in these two countries, yielding different results. The response of those two small European countries has received international attention and continues to be debated by leading economists in the world.

If one looks at GDP growth, both countries are on a growth path. Latvia currently enjoys higher GDP growth than Iceland, but one needs to keep in mind that its GDP fell much more during the crisis and Latvia's GDP remains 8 percent below pre crisis peak. In Iceland unemployment is about 4 percent and only about one third of unemployment in Latvia about 12 percent. In Latvia unemployment is about the same as average unemployment in the EU, but twice the pre crisis level in Latvia. Neither economies has returned to full pre crisis health.

In terms of GDP growth and level of unemployment, Iceland has been successful, but problems related to its large currency depreciation, resulting in household and corporate balance sheet problems remain, and are hotly disputed in the country where the government has limited fiscal space to address those problems. It is also highly questionable if the government should use its limited fiscal space to implement actions that only favour part of the population that can't handle their private debts. One can argue that Iceland has become a society where free riding is becoming popular. Households e.g. demand repeated debt restructuring that eventually will have to be paid by taxpayers and be a burden on the economy and future generations for 
years to come. The current government has fuelled expectations in this area and this behaviour may result in much higher public debts and put further economic recovery at risk. As a result Iceland may continue falling behind the Scandinavian countries in terms of per capita income.

Latvia has also achieved healthy economic growth and unemployment has gone down, but it still remains high. The government of Latvia, via its former PM, has presented the country as a success story for the rest of the world to follow. If one considers the social indicators and measures of income inequality that the EU measures and publishes, Latvia looks bad not only in comparison with Iceland, but also compared with countries at similar income level (e.g. Czech Republic and Slovakia. In fact, if one considers social progress Latvia has more in common with Romania and Bulgaria that have per capita income that is only about half of Latvia's. Under those circumstances one can say that Latvia has shown some success, but the human costs remain high. Latvia can hardly be considered a success in the EU and a model for the rest of the world to follow. Measuring GDP growth only is too narrow. The Latvian prime minister during the crisis considered the Latvian program to be a success, and stated that "The greatest pleasure in life is doing what people say you cannot do..." Neither the former PM nor the government, should take pleasure in seeing the dismal status of human development in Latvia and the EU, and IMF should not declare success when viewing the miserable social progress in Latvia.

Iceland and Latvia were both severely affected by the crisis and the policy response was different, in Latvia's case with fixed exchange rate, and in Iceland with flexible exchange rate and large depreciation. Both countries adjusted and made sacrifices, implementing painful budget cuts. Both countries are enjoying GDP growth well beyond the EU and Euro area and unemployment has gone down although long term unemployment is still a concern in Latvia.

Neither Iceland nor Latvia have yet returned to full economic health and they face future challenges. By damaging the social fabric in Latvia, a burden has been placed on future generations, and many of the youngest and best educated have left the country. In Iceland, the planned debt forgiveness for households and corporate, risks imposing a burden on future generations, encouraging continued free riding, and is likely to result in slower economic growth, with Iceland falling further behind the other Nordic countries in terms of both income levels and living standards.

\section{References}

Åslund, A., Dombrovskis, V. (2011). How Latvia Came Through the Financial Crisis. Peterson Institute for International Economics, Washington, DC, May 2011.

Blanchard, O., Griffiths, M., Gruss, B. (2013). Boom, Bust, Recovery Forensics of the Latvia Crisis. Final Conference Draft to be presented at the Fall 2013 Brookings Panel on Economic Activity, September 19-20. Available at: http:// www.brookings.edu/ /media/projects/bpea/fall\%202013/2013b_blanchard_latvia_crisis.pdf [accessed on May 11, 2014].

Cunska, Z., Ketels, C., Paalzow, A., Vanags, A. (2013). Latvia Competitiveness Report. Stockholm School of Economics in Riga and the Baltic International Centre for Economic Policy Studies. Available at: http://www.sseriga.edu/ en/research/lcr/ [accessed on May 5, 2014].

Commission on the Euorpean Communities. (2009). GDP and beyond-Measuring progress in a changing world. Communication from the Commission to the Council and the European Parliament. Available at: http://eur-lex. europa.eu/LexUriServ/LexUriServ.do?uri=COM:2009:0433:FIN:EN:PDF [accessed on Aprill, 2014].

Darvas, Z. (2013). Where does the youth exodus come from? Available at: http://www.bruegel.org/nc/blog/detail/ article/1103-where-does-the-youth-exodus-come-from/ [accessed on April 7, 2014].

Darvas, Z. (2011). A tale of three countries: recovery after banking crises (No. 2011/19). Bruegel Policy Contribution. Available at: http://www.bruegel.org/publications/publication-detail/publication/663-a-tale-of-three-countriesrecovery-after-banking-crises/ [accessed on September 7, 2013].

Eurostat. (2013). Second estimate for the third quarter of 2013. Available at: http://epp.eurostat.ec.europa.eu/cache/ ITY_PUBLIC/2-04122013-BP/EN/2-04122013-BP-EN.PDF [accessed on March 8, 2014].

European Commission. (2013). Simon Kuznets on GDP and well-being in 1934. Available at: http://ec.europa.eu/environment/beyond_gdp/key_quotes_en.html [accessed on November 7, 2013]. 
European Commission. (2013). President of the World Bank Mr. Robert McNamara on GDP and social equity in 1973. Available at: http://ec.europa.eu/environment/beyond_gdp/key_quotes_en.html [accessed on November 7, 2013].

European Commission. (2012). Europe 2020. Available at: http://ec.europa.eu/europe2020/europe-2020-in-your-country/latvija/country-specific-recommendations/index_en.htm [accessed on March 7, 2014].

Hilmarsson, H. P. (2013). Small states and big banks - the case of Iceland. Baltic Journal of Economics, Vol. 1, p. 31-48. Available at: http://www.biceps.org/assets/docs/bje/bje2013_no1/Policy_paper_2 [accessed on May 7, 2014].

IMF. (2013a). World Economic and Financial Surveys. World Economic Outlook (WEO). Transitions and Tensions, October. Available at: http://www.imf.org/external/pubs/ft/weo/2013/02/ [accessed on November 7, 2013].

IMF. (2013b). IMF Country Report, No. 13/28. Republic of Latvia 2012 Article IV Consultation and Second Postprogram Monitoring Discussions. Available at: http://www.imf.org/external/pubs/ft/scr/2013/cr1328.pdf [accessed on May 11, 2014].

IMF. (2012). Latvia and the Baltics - a Story of Recovery by Christine Lagarde Managing Director. International Monetary Fund Riga, June 5, 2012. Available at: http:/www.imf.org/external/np/speeches/2012/060512.htm [accessed on December 7, 2013].

IMF. (2011). IMF Survey Magazine: Countries \& Regions. Available at: http://www.imf.org/external/pubs/ft/survey/ so/2011/surveyartf.htm [accessed on November 11, 2013].

IMF. (2008). Iceland: Financial System Stability Assessment - Update. Available at: http://www.imf.org/external/pubs/ ft/scr/2008/cr08368.pdf [accessed on April 5, 2014].

Krugman, P. (2011). They Have Made a Desert, and Called it Adjustment. The New York Times, December 7. Available at: http://krugman.blogs.nytimes.com/2011/12/07/they-have-made-a-desert-and-called-it-adjustment/ [accessed on December 7, 2012].

Samuelson, P., Nordhaus, W. (1995). Economics. 15 edition. Mcgraw-Hill.

Sarkozy, N. (2009). French president Nicolas Sarkozy at the unveiling of the Stiglitz. Report in Paris on 14 September 2009.

Statistics Iceland. (2013a). Wages, income and labour market. Available at: http://www.statice.is/?PageID=452\&itemi $\mathrm{d}=$ ef4be73d-87b0-4ccf-ba2e-b613243dca57 [accessed on November 11, 2013].

Statistics Iceland. (2013b). Quarterly national accounts. 3rd quarter 2013. Available at: http://www.statice.is/ Pages/444?NewsID=9778 [accessed on December 7, 2013].

Stiglitz, J. E. (2005). Growth may be everything, but it's not the only thing. Foreign Affaris. November/December 2005 Issue. Available at: http://www.foreignaffairs.com/articles/61208/joseph-e-stiglitz/the-ethical-economist [accessed on May 2, 2014].

Stiglitz, J. E., Sen, A., Fitoussi, J. P. (2013). Report by the Commission on the Measurement of Economic Performance of Social Progress. Available at: http://www.stiglitz-sen-fitoussi.fr/documents/rapport_anglais.pdf [accessed on November 11, 2013].

Vanags, A. (2013). Latvia's Exports: the Real "Success Story". Baltic International Centre for Economic Policy Studies, Research Report. Available at: http://biceps.org/assets/docs/izpetes-zinojumi/Latvias_exports [accessed on April 11, 2014].

World Bank. (2013). E11 Regular Economic Report, Issue 27, June 2013. The World Bank - Europe and Central Asia Region. Available at: http://www.worldbank.org/content/dam/Worldbank/document/eca/eu11-rev-report-jun-2013. pdf [accessed on December1, 2013].

Yin, R. K. (2009). Case Study Research. Design and Methods. 4th ed., Vol. 5. California: SAGE Inc.

\title{
ISLANDIJA IR LATVIJA: EKONOMINE் IR SOCIALINE் KRIZE்
}

\author{
HiLmar Pór HiLmarsson
}

Akureyri universitetas (Islandija)

\section{Santrauka}

2008 m. pasaulinė ekonominė ir finansų krizė gerokai paveikė Islandiją ir Latviją, tačiau šių šalių ekonominis vystymasis iki krizès ir pasirinktas atsakas ị krizę bei jos rezultatai skyrèsi. Abi šalys krizès 
laikotarpiu gavo paramą iš Tarptautinio valiutos fondo (TVF), kuris vèliau teigiamai ịvertino abiejose šalyse vykdytas reformas. Šiame straipsnyje apžvelgiama ir ịvertinama Islandijos bei Latvijos situacija po krizès tiek ekonominiu, tiek socialiniu požiūriais. Aptariama, kaip kitos valstybės ir tarptautinès institucijos paveikè reformų programas Islandijoje ir Latvijoje.

PAGRINDINIAI ŽODŽIAI: mažos valstybès, Latvija ir Islandija, pasaulinè krizé, ekonomine politika, privatizavimas.

JEL KLASIFIKACIJA: H12, E63, L33 